\title{
Cultivating Practitioners of Democratic Civic Engagement
}

\author{
Novella Zett Keith \\ Temple University
}

\begin{abstract}
How can we support campus-based practitioners of civic and community engagement in moving from normalized engagement toward practices that engage others democratically and respectfully across borders created by social race, class, gender, status, and other markers of difference? The article presents a framework derived from practice theory, a social science perspective that has influenced professional and organizational studies. The framework, which is meant as an aid for practice, integrates Bourdieu's habitus, field, and capital with the theory of practical wisdom or phronesis. Bourdieu helps us understand how normal practice is constituted while phronesis provides the tools to consider practice that is ethical, democratic, border-crossing, and wise. Two mini-cases drawn from a graduate and an undergraduate course in urban education feature engaged practitioners in school settings and provide illustrations for the theory. The concluding section discusses implications of this way of framing the cultivation of community-engaged practitioners for the practice of reflection, course design, and research.
\end{abstract}

The question I am asking in this article is how to support campus-based practitioners (students, faculty, and staff) in moving from the normalized practice of engagement - still too often practiced as charity, spectatorship, activity and place, or outreach (Bheekie \& van Huyssteen, 2015; Saltmarsh \& Hartley, 2011) - toward the capacity to engage democratically and respectfully across borders created by race, class, gender, professional and educational status, and other markers of difference. Constituted by webs of unequal power, borders typically pose obstacles for campus-community partnerships and democratic engagement. ${ }^{1}$

To this end, the article presents a theoretical framework that I believe can help us consider what influences normal or habitual practice and its transformation. Theory here is intended as a heuristic to support understanding and practice rather than as an explanatory and predictive model: It provides thinking tools that can help us make new connections, construct differently what we know, and ask questions that lead to new knowledge and ways of seeing and doing. I sought theories that could advance community-engaged practitioners on a transformational path, where what was wanted was change in both person (mindset, dispositions, and so on) and service-learning/community engagement (SLCE) practice while also considering ethical practice.

Working with community-engaged practitioners (CEPs), among whom I include myself, has been an important focus of my professional life, and I have come to think of this work as a cultivation or an organic process that involves a collaboration with na- ture - here, the gifts and qualities of practitioners. Cultivation should be about providing fertile ground and good conditions for seeds to grow into the best possible versions of themselves. My involvement in social-justice oriented service-learning and what is now called civic and community engagement goes back about twenty-five years. Of late, I have been moved particularly by the call to action around $A$ Crucible Moment (National Task Force on Civic Learning and Democratic Engagement, 2012) for higher education to commit more fully to preparing graduates for democratic civic engagement. I hope to make a contribution to an understudied area in the field by focusing on transformative practice (more than transformative learning), and those moments in practice that can become turning points toward more democratic, equitable, and ethical engagement. Understanding process and practice can complement outcomes-oriented work on the attributes of the community-engaged graduate and professional (e.g., see Clayton, Bringle, \& Hatcher, 2013) and initiatives on the preparation of community engagement professionals (Dostilio \& McReynolds, 2015; McReynolds \& Shields, 2015; http://compact.org/initiatives/professional-devel opment-training/).

The central idea of the article is to see SLCE through the lens of practice. Practice is commonly used either as a qualifier of specific domains (e.g. clinical practice) or as a reference to learning through repeated action. As used here, however, it references a family of theories or perspectives termed practice theory, comprised of different strands united in problematizing everyday (including professional) activ- 
ities through insights from the fields of sociology, anthropology, and organizational studies (Nicolini, 2012). Whereas scholars informed by the cognitive and behavioral sciences generally take the individual as a starting point, practice theorists locate the practitioner and the practice at the intersection of socio-cultural-discursive, economic-material, and political arrangements that both enable and constrain the practice.

The focus, thus, is on practice- and the practitioner-in-context, where contextual factors may include language and forms of speaking, tools, and material objects (including bodies), as well as ways of relating and exercising power, solidarity, authority, and privilege. Kemmis and his colleagues (2014) refer to these, respectively, as sayings, doings, and relatings. Through this lens, the actions of practitioners emerge from the interrelatedness of all aspects - present and historical, experiential and structural, individual and group-based - that enter into a given situation in which they are involved. I used the term 'context' above because we are familiar with this language; the theories refer instead to the practice site, situation, or (in the version I use) field. Context can be seen as a container for the practice, whereas the site is about "a set of conditions that make the practice possible though they do not determine it" (Kemmis, Wilkinson, EdwardsGrove, Hardy, Grootenboer, \& Bristol, 2014, p. 14).

For the practitioner, thus, it is not only a matter of being cognizant, say, of the historical origins, structural aspects, and current conditions impacting the community (see Dreese, Dutton, Neumeier, \& Wilkey, 2008) but of how the material aspects of that setting enter into the practice site, or how a particular faculty, staff, or student participant responds, based on her/his prior experiences and history, and what actions are possible and are taken. Additionally, how one engages in this practice situation goes beyond positionality and identity say, a white middle class college student entering this school and neighborhood motivated to become a community engaged professional - and involves the student's and community partners' prior embodied experiences, their orientations and desires, capacities, skills, and qualities as they interact in and with the situation. ${ }^{2}$

Thinking with practice means shifting the focus of course and program development, pedagogy, and research from the individual unit, including individual learning and development to a wider lens such as the activity and activity 'system'. Community service learning might thus be seen, as McMillan (2011a) suggests, as "two communities of practice interacting via one activity system and engaged in joint activities" (p. 557). Thus the unit of analysis for research is the 'boundary zone' where the service-learning project takes place and the practitioner is a 'boundary worker.' The practitioner still retains an important place in this perspective, especially in the versions of practice theory I use, but his or her cultivation must take this complex system into account. Through a practice theory lens, organizations can be seen as ecologies and architectures of interdependent practices, where social regularities are produced and reproduced through webs of mutually interactive and relational processes taking place in particular sites. This does not mean that the oppressive nature of some social relations is, suddenly, easy to change. However, interactions always leave room for unpredictability through creativity and innovation even within existing structures, and as such practice theories help us see reality as somewhat more fluid, opening up ways to rethink both persistence and change and consider how engaging in practices differently, in specific sites, might expand the limits of what is possible.

Practice-based approaches have received renewed attention in the last twenty years, even generating new terms such as the practice turn, practice-based studies (PBS) and practice-based education (PBE) (Darling-Hammond, Chung Wei, Andree, Richardson, \& Orphanos, 2009; Gherardi, 2008, 2009; Kinsella \& Pitman, 2012; Macintyre Latta, \& Wunder, 2015; Perry, 2015; Shulman, 2007). Their meanings do vary and, as Boud and Drew (2013) remark, their use may at times constitute simply a new label. In the SLCE field, social practice theory is represented by approaches that use situated learning and community of practice $(\mathrm{CoP})$. At times these are paired with complementary theories, including critical social theory and critical discourse analysis, which address tendencies in the CoP framework to overemphasize individual learning and undertheorize power. To cite a few examples, Nemeth and Winterbottom (2016) put "a socially situated theory of learning in conversation with [Butin's] poststructuralist service-learning" (p. 313). McMillan (2011b) bridges CoP and activity theory, which she presents as an extension of Vygotsky's (1978) work that "brings history and power into the picture . . . and provides a link between micro and macro perspectives and contexts" (p. 110). Carrington, Deppeler, and Moss (2011) draw from critical social theory and collaborative inquiry in CoPs to engage teachers (pre-service and in-service) in critical dialogue about professional learning; they demonstrate how their continuum of teacher learning led to changes in teachers' beliefs and knowledge that were reflected in new, contextually appropriate teaching practices. Other 
scholars and researchers approach the field in ways that are partly congruent with practice theory. I will return to the work of Butin (2007), Kiely (2005), and Mitchell (2014) in this regard. Together, these and other contributions suggest an ongoing search in the SLCE field for approaches that are broadly aligned with or friendly to practice theory.

The remainder of the article is organized as follows. I begin with two vignettes that anchor the theoretical presentation and return to them after that presentation. The vignettes center on two SLCE practices that will be familiar to readers: practitioner reflection on experience and course or program design. The framework provides a broad understanding of ethical practice that puts the practitioner-in-context at the center. It also provides new ways of thinking about reflection and design and the cultivation of ethical practitioners. The concluding sections consider the framework and vignettes in light of relevant SLCE literature and the implications of the framework for SLCE practice and research.

\section{Two Vignettes}

Both vignettes are drawn from courses taught using a capacities or assets stance vis-à-vis community partners and involved students in servicelearning/partnership projects in impoverished urban neighborhoods. I was the instructor in one course and part of an instructional team in the other. Given space constraints, I hope readers will accept my assertion that the courses were designed to meet standards of good quality as broadly summarized by Felten and Clayton (2011) and, for reflection, Eyler (2002). In particular - and the importance of this will become clearer once the framework has been presented - considerable time was devoted to the students sharing their life experiences in relation to their community-based work.

The first vignette is drawn from a graduate course on campus-school-community partnerships taught in fall 2015. This class was partly co-designed with the students and was modeled on a CoP that included sharing stories and experiences, providing support through the inevitable challenges, and mutual learning. The second vignette offers a snapshot of a four-year partnership (1999-2003) between a university, high school, and coalition of neighborhood groups; the college course was part of the teacher education core and was designed so students would both experience service-learning and begin to learn how to use it in their future teaching. Each vignette includes an abbreviated sketch of the context and of a practice situation that constituted a critical incident and stimulated reflection and change. ${ }^{3}$ I invite readers to think actively about the vignettes and issues they evoke while reading the theoretical framework, perhaps beginning to "find the theory" in the everyday. ${ }^{4}$ The later discussion of the first vignette will focus mainly on Cynthia's habitus, virtues, and sensemaking. The discussion of the second vignette will also focus on enacting the good. ${ }^{5}$

\section{A Civically-Engaged Practitioner Reflects on Her Habitus}

The context. Cynthia is a VISTA working as a school-community coordinator in a middle school located in a high-poverty African American neighborhood. She is a middle class white woman in her mid-20s in her second year at the school and in a Master's program at Temple University, where she is enrolled in a course on campus-schoolcommunity partnerships. She considers herself a successful practitioner in this setting and offers in support for her self-evaluation that "only a few months into the [first] year, my principal begged me to come back for a second year." A major requirement of the course is a partnership project that typically takes place at the students' work site (schools and other youth- and education-oriented organizations). Students also complete an autobiographical narrative and two critical reflections on critical incidents in their partnerships.

Cynthia's project centers on developing greater parental engagement at her school, and as the semester progresses she begins to focus on her relationship with the parent coordinator, Gaby, a middle-aged Haitian woman who was recently hired for that position. It is important to Cynthia and the school that the two have a good working relationship; for Cynthia, this includes valuing $\mathrm{Ga}-$ by's and the community's actual and potential resources or capital.

The critical incident. Cynthia's critical incident shows her struggling internally with her perception of Gaby, which had been quite positive but has started changing, potentially jeopardizing the relationship. Cynthia links this change to an interaction she had with her principal, during which the principal expressed her frustration with Gaby's conduct at a parent meeting. Principal Davis is an AfricanAmerican woman whom Cynthia describes as an excellent principal and a "personal super-hero" of hers. Cynthia writes:

Initially, both outwardly and internally, I defended Gaby to Principal Davis and shook off her remarks. My inner monologue went something like this: Parents love Gaby's liveliness. Davis just has a lot going on right now and clearly hasn't had time to fully appreciate her 
energy. No big deal. The next time I saw Gaby, however, I started to notice that I acted differently towards her. I was slightly less receptive ... I was short with my words and slightly more impatient. ... I was irritated by behaviors that had, only weeks prior, inspired me. This caused me to reflect on my thoughts and actions ... What were the skills and attributes I liked about Gaby? Had they been an asset to [the school] or how could they be? Why was I refusing to recognize them all of a sudden?

\section{Changing Course Elements in a Campus-School- Community Service-Learning Partnership}

The context. The partnership created teams of college and high school students working together on service-learning projects. The high school students were enrolled in the school's only collegebound small learning community and were in the leadership group for the school's Youth-Driven Community-Service Center. The school was in a hyper-segregated high-poverty neighborhood and its students were all African-American or Black. The college students were about $75 \%$ White and mostly of working- or middle-class background. All the students participated in a joint class, held at the high school, which brought together the two student groups for about ten weeks of the college semester. The joint group was supported by an instructional team that included community, high school, and university personnel. The projects that the student teams planned and implemented were in the neighborhood and were selected and planned in collaboration with the community-based organization. With regard to goals, the high school and community partners wanted to engage young people in empowering community-based work and the college partners were in agreement with this goal; the high school and college students had various motivations but they all needed to complete a servicelearning project and other course requirements; and all the instructors wanted to apply the principles of sound service-learning practice and collaboration across social divides.

The critical incident. It is the end of the second year and the instructional team is meeting to evaluate the work accomplished. Team members take turns sharing their perception of what is going well and what needs attention. There are successes on the part of both the high school and college students. The service-learning project requires the teams to conduct research on community needs, which has really helped the high schools students become comfortable in an area that had constituted a huge stumbling block. The college students have been an invaluable resource in making college more real and accessible for the high school students, as they have taken their teammates to campus, their residences, and even their classes. The college students are enjoying being in a school and getting a first taste of their future profession. They have mostly overcome their initial fear of the neighborhood, have developed relationships, changed their views, and begun to come to grips with racial and class privilege. Memories of the final joint celebration on campus are still with us and fill us with excitement and pride that we were able to create this community across these borders.

Everything is not great and we have all noticed problems around collaboration in the student teams. Communication is often one-way, with college students directing and managing the work, and each of us has intervened at times to interrupt their taking control of group talk and making arbitrary decisions. For their part, some college students, reverting to the normalcy of seeing problematic behaviors simply as personal character deficits, have complained about their high school teammates 'fooling around' and not fulfilling their responsibilities. It is clear that we will need to put more effort into team building. We are almost ready to start considering solutions, when Sharon, one of the two high school teachers in the team stops the process and makes a simple and powerful statement: "My students are becoming passive."

Both critical incidents raise questions about cultivating democratic practitioners of civic engagement in border-crossing settings. Both involve seasoned, competent practitioners (Cynthia and her principal in the first vignette, the leadership team in the second vignette) and relatively novice ones (Gaby in the first vignette and the high school and college students in the second vignette) - all learning to practice as civically engaged partners in cross-border settings. I now take a detour into the theories. My primary focus is on campus-based practitioners. I hope readers will not take it as a sign that I am privileging this group: My position is that, in border crossings, the partners who come from more dominant social positions have a special responsibility and, quite frankly, more to learn.

\section{Practice Knowledge and a Practice Theory Framework}

\section{Practice Knowledge: Epistemological Divides}

In an article exploring faculty and servicelearning community partners' theories of learning, Bacon (2002) hypothesizes "that members of different groups [or discourse communities] will 
differ . . . in how they use language and that differences in language use may reveal underlying differences in the group's values, goals, or beliefs" (p. $35)$. Analysis of focus groups revealed significant overlaps but also three main differences between the faculty and community partner groups. Faculty tended to (a) identify themselves more as knowers and experts than as learners; (b) examine students' words in evaluating successful learning; and (c) value group work but represent learning as an individual activity. Community members tended to (a) identify as learners and see learning as a continuous activity based in experience; (b) consider the ability to take action as evidence of successful learning; and (c) subordinate the individual learner to the group's collective development, talking "less about specific instances of interaction such as discussion and ... more about relationships developing over time." (p. 41)

Those familiar with cognitivist and situated perspectives on learning will see here the signs of the two discursive communities: the faculty in the study were more cognitivist and community members were more situativist. Bacon (2002) suggests that these divides are slowly being dismantled and remarks that all participants were developing a more comprehensive view. She attributes these remaining differences "to where these people [faculty and community partners] spend their time and what sort of learning they habitually witness and experience" (p. 43).

Epistemological divides such as these are common in academic fields. Each of these theories of learning falls in a broader divide that Schwandt (2005) terms the scientific knowledge tradition and the practical knowledge tradition. The scientific knowledge tradition values analytical and scientific approaches that follow the precepts of the physical sciences and produce decontextualized and generalizable knowledge. Objectivity and certainty are important values here. The researcher is an expert who generates knowledge through rigorous methods that whenever possible approach those of the physical sciences; practitioners (here, the community partners) look to the university for knowledge that will help them in their practice. One example of this approach is evidence-based practice (Biesta, 2007) promoted, among others, through the Institute of Education Sciences' What Works Clearinghouse (http://ies.ed.gov/ncee/wwc/). The practical knowledge tradition is aligned with situated learning, communities of practice, and practice theory. Briefly, knowledge is generated in practice and thus is context-dependent; it is embodied rather than being situated in cognitive processes alone. Ambiguity and uncertainty are the norm.
In practitioner-oriented fields, the divide is most frequently discussed in terms of the legitimate sources of practitioner knowledge. But Bacon's findings point to a more subtle manifestation of it. She remarks on a curious absence in the community partners' conversation: "these participants spoke about faculty and graduate students in terms of their expertise, [but] they did not claim expertise for themselves (though all four had college degrees). Instead, they tended to represent their own knowledge as something arising naturally from their experience" (p. 39). We seem to be in the presence of an internalized self-marginalization: These practitioners' description of their own knowledge fits the tenets of the practical knowledge tradition, but they do not seem to accord value to it. The only site constructed as having legitimate knowledge (expertise) is the academy. Experiential knowledge is useful but suffers from a lack of recognition and has no language. Thus, they cannot be experts in their own right.

I believe that Bacon's curious absence is the sign of a border that the framework I propose can address. Introducing terms that are explained in the next section, the practice knowledge tradition is embodied in the habitus of the practitioners, but so is its devaluation as an asset. If education is a field and knowledge is one of its important resources, academics are winning the game. Cultivating practitioners would thus require the valorization of practitioner knowledge, not only through words, but through experiences of its value.

Before going further I should dispel a misperception this statement might create: I am not suggesting that, in a search for bridging the two knowledge communities, academics should abandon careful thought and rigorous scholarship and research but that our definitions of rigor and science should be expanded to include approaches that are relevant for practice (e.g., see Flyvbjerg, 2001; Nicolini, 2012). Nor am I suggesting that researchers cede the ground to practitioners' understanding of their practice in a reversal of the current relationship. Engagement calls for a serious rethinking of the relationship between research and practice, and practitioners and researchers - as recent activities in the field indicate.

\section{Practice Theory: Thinking Tools for Cultivating SLCE Practitioners}

The framework I propose brings together two strands of practice theory. The first is the construct of habitus-field-capital developed by Pierre Bourdieu, a French social theorist whose work has deeply influenced how we understand everyday 
practice. The second is modern-day or applied (neoAristotelian) phronesis or practical wisdom, which is about ethical and wise practice. This combination works well because the constructs are comprised of parts that are both similar and complementary. Together, they provide thinking tools that will help us delve into the movement of the practitioner from normalized to wise (and ethical) practice.

Two parts of Bourdieu's construct, habitus and capital (especially cultural capital), are well-known and have been used extensively in the sociology of education, contributing especially to our understanding of what is termed 'cultural reproduction' - how schooling actually generates (or reproduces) social inequality (see Bourdieu, 1977, 1989; Bourdieu \& Passeron, 1990). Others have also used the framework in the service of equitable change, which is how I envision it here (e.g., see Horvat \& Davis, 2011; Yosso, 2005). However, the three components of the construct (the final one is field) are less frequently understood and used as a single, interactive entity (Townley, 2014; Zembylas, 2007). One of the few instances I have found comes from SLCE. As Jagla, Lukenchuk, and Price (2010) explain, they have extended Bourdieu's tripartite construct and combined it with the relational ethics of Noddings and Levinas to develop the construct of a service-learning habitus (SLH). The approach is novel and potentially interesting, though I have not delved into it sufficiently to consider its relationship to my framework, because the purposes are different. In addition, my approach to Bourdieu remains closer to his original work, though I also combine it with the ethical thought of different scholars.

As I use it, Bourdieu's theory helps us grasp the relatedness between practitioners' dispositions, social environments, practice settings, and the motivation to strive for what is defined as excellence or high quality performance in these settings. I then integrate Bourdieu's theory and a phronetic understanding of the cultivation of wise practitioners and practice. The aim of phronesis is to infuse practice with an ethics centered on the promotion of human and community flourishing or lives worthy of human dignity (termed the good). This ethics is situational: It is not about an abstract and general common good but about what may contribute to flourishing, constructed (most often) dialogically, as achieving something of value in the situation at hand (Neher \& Sandin, 2016). Classical phronesis was elitist, its definition of virtue grounded in the agreement of a virtuous community, and it did not address power relations. Current versions address power (see especially Flyvbjerg, 2001; Schram, 2012) and provide remedies that include dialogue and openness to multiple narratives and standpoints (Coulter \& Wiens, 2002; Hursthouse, 1999). Together, both theories shed light on what shapes existing practices and create a path for envisioning possibilities for change.

An additional clarification is needed before moving on. In Bourdieu's framework, excellence in a given field is not equated with ethical action, as is the case in the phronetic framework. For example, institutions may achieve 'excellence' by manipulating quantitative performance indicators (metrics) that distort the true purposes of higher education. Similarly, a professor at a university may be rewarded for practicing engagement as outreach and even using the community as a laboratory, both of which are problematic for proponents of democratic engagement and usually for community partners. ${ }^{6}$ The ethical dimension of Bourdieu's framework is in its exposure and critique of the power and privilege involved in these 'games.' Foucault's notion of discourse and its normalizing functions is a useful critical addition. Discourses are systems of thought and practices that circumscribe what can be said and thought. They support practices, many of which are oppressive, that we think of as normal, but are instead normalized through workings of power that are largely invisible (Foucault, 1977/1995). Disturbing and interrupting these normalcies, both in people and in social, material, and political arrangements, is necessary for changing practices. Let me now discuss each contribution in greater detail.

\section{Bourdieu's Habitus-Field-Capital}

Habitus. Think of habitus as a background matrix that is constituted in the course of our experiencing, as active agents, the everyday world, including its power relations - in actuality, vicariously, and through personal and group memories, narratives, and histories. These become part of who we are and our sense of 'how things work' not only insofar as we remember and actively refer to them, but as embodied dispositions and orientations that guide our perceptions, interpretations, and actions. The schema that generates these preferences is both personal and group-based and is generally outside our conscious awareness: we simply prefer certain foods, feel comfortable speaking in certain ways. If we are academics, analytical work may feel more natural than practitioner work; and if we are also teachers, thinking tools such as learning theories and pedagogies will likely feel more natural than practice theories. This is important with regard to SLCE: arguably, it is a practice field. What is left out when it is informed mainly by theories of teaching and learning - through the habitus of educators? 
The best known definition of habitus has it as the "generative principle of regulated improvisation" (Bourdieu, 1977, p. 78). If you think about it, it becomes interesting and may even feel right. Our experience is that we are all unique individuals, who are different, seldom predictable, creative, and are certainly 'agents' constantly 'improvising' as we interact in the world. What we are less aware of is that we act individually, spontaneously, and creatively in the context of something - Bourdieu's 'matrix' is one way to put it - that regulates what is normal and possible for each of us. The source of this regulation is the social milieu and social relationships or, in Bourdieu's terms, the 'field'. Habitus and field thus account for the predictability-unpredictability of the everyday (also see Crossley, 2013).

Field. Bourdieu (1985) often uses terms without fully defining them and this is true of fields. He writes about them as relatively stable social spaces or networks of relationships in which people are distributed by virtue of the types of capital economic, social, cultural and symbolic - that they possess and that have currency in each field. Some fields or social spaces intersect and are similar, which means that members of a social group and nearby groups have a similar habitus and feel more comfortable interacting with one another than with people whose 'coordinates' in the social space are far removed from theirs. This basic comfort is what keeps us in or close to our fields and what allows us to strive for and be our best in those fields.

Capital. This thinking tool refers to anything that has value in a given field and can be exchanged for profit - similar to an ace in a game of cards in which aces matter. People use the capitals available to them to compete for power and positional advantage and generally to 'play the game'; but symbolic capital is the most important because, like a wild card, it allows its holders to define what has value in the field (Bourdieu, 1985, 1989). Why is standard English 'better' than other ways of speaking? Bourdieu would say that thinking with symbolic capital, it is so because canonical writers, educated elites, and others who 'matter' possess the symbolic capital that allows them to set the standards. Some of us experience standard English as normal, while for others it is a border that only can be crossed by becoming assimilated or excellent at code switching. ${ }^{7}$ Bourdieu's capital helps us see anew the social and material realms. As an example, it helps us to see clothing, tastes, ways of speaking, and gestures as sites of symbolic struggle through the use of cultural capital. These material differences matter: When crossing borders into the community, for instance, what counts as 'dinner'?'

Bourdieu incorporates here an important notion that is central to the critical/conflict traditions: fields are held together in tension, often through subtle forms of power/violence that operate at the conscious and unconscious levels. What constitutes capital in a field can be redefined through contestation. In this vein, constructs such as 'practitionerscholar' (see McReynolds, 2015; McReynolds \& Shields, 2015) can be seen as attempts to reposition the practitioner's knowledge as valuable capital. However, it takes symbolic capital to accomplish this; organizational leaders may not accept the revaluing and even deny rewards to would-be change agents. This also is true of proposals for a dialogical and multivocal SLCE epistemology (see Hoyt, 2010; Saltmarsh, Hartley, \& Clayton, 2009) and for more inclusive criteria for faculty tenure and promotion (e.g. Glass, Doberneck, \& Schweitzer, 2011). Through Bourdieu's lens, making traditional practices problematic in these ways signals a symbolic struggle being waged for recognition of community engagement as a field, which involves contesting what constitutes capital, changing rules of the game, and putting forth different models of exemplary academics.

Habitus-field-capital as a construct. In what is depicted sometimes as a formula, practice is created though the intersection of habitus with capital and field position. To clarify this interaction, Bourdieu uses a well-known metaphor: a game. The game is played by players who are differently positioned and skilled, have a 'feel for the game' (sens pratique), the motivation to play, and an interest in doing it well (Townley, 2014). Some may also decide that playing the game is not worth their while (this is one way to think about student disengagement). The game (field) has rules by which the players agree to play and resources, material and otherwise, that make it possible to play. Differential access to the field's valued resources (capital) creates disparities, which the more skilled or dominant players try to maintain; some players are more creative and innovative (the personal habitus) and become quite exemplary through the interaction of habitus, capital, and field. One of the dangers of metaphors, of course, is that they oversimplify what is a much more complex reality. ${ }^{9}$

\section{Phronesis}

Aristotle's Athens was dominated by technocratic and instrumental thinking, which he sought to correct by considering the purposes toward which knowledge is put (Gadamer, in McGee, 1998). He proposed three interconnected orientations to knowledge: episteme, techne, and phronesis. Episteme pertains to context-independent knowledge 
involved in the pursuits of science and logic, while both techne and phronesis are oriented to action in the world. Techne pertains to craft, technical knowledge, and skills, or know-how. Phronesis, as currently understood (e.g., 'applied phronesis') includes questions of values and power plays that are relevant to practice, as well as an "intimate familiarity with the contingencies and uncertainties of various forms of social practice embedded in complex social settings" (Caterino \& Shram, 2006, p. 8). This sort of practical knowledge relies on judgment rather than techniques: Each situation is unique and the action that brought forth the good yesterday may not do so today. As educators know from experience, every group is different: their work is thus part of the practical knowledge tradition and requires cultivating practical judgment. ${ }^{10}$ Noel (1999) brings together three distinct but interwoven aspects of phronesis adopted for this framework: embodying the virtues, sensemaking (making sense of the situation), and constructing and enacting the good.

Embodying the virtues. Phronesis posits an intimate connection between who we are, how we make sense of the world around us, and what we do. ${ }^{11}$ Virtues are 'ways of being excellent' that are cultivated and practiced in communities and become embodied as our character and as capacities and motivations to act in ways that further the good. Virtue ethics, in turn, involves the aspiration and motivation to develop a virtuous character and act accordingly (Hursthouse, 1999; King, 2015). Three issues need clarification. First, virtues are not synonymous with moral qualities; in fact, a distinction is usually made between (overlapping) intellectual, moral, and civic virtues. Intellectual virtues, which support learning and sound thinking, include intellectual curiosity, courage, the disposition to consider issues carefully and thoroughly, and qualities Dewey considered necessary for reflection (see Rodgers, 2002): wholeheartedness, directness, open-mindedness, and responsibility. Moral virtues are akin to the qualities of a good neighbor, such as being trustworthy, kind, and compassionate. Civic virtues include the disposition to consider the wellbeing of others and work collaboratively toward the common good. Respect for freedom, openness to diversity, and all that goes under civic mindedness and social citizenship are also part of the mix (see Baehr, 2013; Bringle, Studer, Wilson, Clayton, \& Steinberg, 2011; Hatcher, 2008; Kreber, 2016; Ladson-Billings, 2004; Musil, 2009).

Second, given that the overall purpose of phronetic action is to reach toward a situated and dialogically constructed good, what counts as a virtue is also situation-dependent. For instance, creativity and a sense of humor may be important when a situation is at an impasse. Research with community partners tells us that they value qualities such as respect, openness, mutuality, interest in the community's history, and the like (Dreese, Dutton, Neumeier, \& Wilkey, 2008; Sandy \& Holland, 2006; Stoeker, Tryon, \& Hilgendorf, 2009). Again, however, it is not a matter of generic qualities but of the qualities that can help achieve a situated good.

Third, the expression of virtues needs to be balanced. This may mean treading a path between excess and deficit: For instance, an excess of respect could turn into subservience. Sternberg's (2003) 'balance theory of wisdom' calls for the relative weighting of various interests (intrapersonal, interpersonal, and extrapersonal) and the balancing of three possible courses of action: "adaptation of oneself or others to existing environments; shaping environments in order to render them more compatible with oneself or others; and selection of new environments" (p. 157). Judgment is important in weighing these aspects, as one is guided by the potential of various plausible alternatives for achieving some good in the situation at hand.

Sensemaking: Making sense of the situation. Sensemaking is an open-ended inquiry process that includes the body and multiple ways of knowing, such as felt sense and intuition, and integrates creativity, character and intellect, cognition and affect. Weick, Sutcliffe, and Obstfeld (2005) describe it as "being thrown into an ongoing, unknowable, unpredictable streaming of experience in search of answers to the question, 'What's the story?'” (p. 410). Or, better, what are the stories - what different ways of narrating this event are there? Whose voices are speaking and whose are silent, marginalized, or even elided from history? (Yalowitz, Malandra, $\&$ Keith, 2015). Sensemaking is thus about constructing meaning in ways that include one's personal beliefs and experiences so as to move toward actions consistent with these perceptions (Mitchell, 2014). Meaning construction is always a collective process, even if at the moment we are alone. Two central processes are situational perception (principally, discernment) and insight. The first refers to "finely tuned habits of salient focusing" (Dunne \& Pendlebury, 2003, p. 207), while insight has to do with the ability to grasp seemingly obscure cues. Both are cultivated through experience with and reflecting or intuiting from a multiplicity of cases (see Flyvbjerg, 2001).

Weick, Sutcliffe, and Obstfeld (2005) studied sensemaking as a process and practice in organizations. Like Bourdieu's habitus-field-capital, this construct and research capture and describe the world as it is. It may include directing our atten- 
tion to what we want to see and not seeing what we "passionately desire to ignore" (Argyris, 1991; Felman, 1982). Phronetic sensemaking involves constructing meaning through personal qualities, beliefs, values, and an orientation that guide a search for the possibilities for the 'good' that a situation might hold. When the Citizen Scholars in Mitchell's (2014) study make sense of their lived experiences through a social justice lens, they are not putting into action a code of ethics: They are enacting who they are and are striving to be. According to virtue ethics, it is one's character and the community in which it is cultivated that provide guidance: A wise (or virtuous) practitioner is motivated to make sense of situations by considering how to resolve them in ways that advance human flourishing for all concerned. Ethics thus enters the very process of understanding the practice situation and our engagement in it. Mitchell explains that "service-learning invokes a number of cues to facilitate sensemaking regarding social justice" (par. 2 ). The anchors here are one's virtues - a passion for social justice, to be sure, a willingness to doubt oneself, tolerance for ambiguity and uncertainty, humility, and the capacity to express them in the particular 'streaming of experience' in which we are immersed. Perhaps it is by "listening eloquently" or (my favorite) "negotiat[ing] traffic at the intersection where worlds collide" (Musil, 2009).

Constructing and enacting the good. The process here is about resolving on a line of action. Shotter (2012) describes it as "moving around within a landscape of possibilities . . . being spontaneously responsive to the consequences of each move, and judging which one (or combination of moves) seems best in resolving the initial tension aroused in one's initial confusion" (p. 253). While the fluidity and openness of this process may seem daunting, especially to the novice practitioner, thinking about it as practical reasoning and the somewhat more structured deliberation may help. Mathews (2004) defines deliberation as weighing "the possible consequences of various approaches to a problem against all that we consider truly valuable" ( $\mathrm{p}$. 8) (also see Pruitt \& Thomas, 2007).

According to Toulmin (2003) practical reasoning is substantive, appropriate to the demands of the situation, and marked by a search for a plausible solution rather than a right answer. In Freire's terms, this might mean assessing the limits and possibilities of a situation: what is real (the status quo), what is desired (the ought), and what is possible (the situated good). Again, we sense the presence of power as the practitioner operates on the tension line between limits and possibilities (Boyte $\&$ Fretz, 2010). Applied phronesis offers four spe- cific questions for sensemaking and deliberation that put power and values at the center. Action (or the last question, "what should be done,") must be preceded by practitioners' mindful search for the workings of power in the practice situation ("where are we going?" and "who wins and who loses, by which mechanisms of power?") and ethical and value considerations ("is it desirable?") (p. 162). As Barker et al. (2011) remark, the process is not meant to be expert-driven; it is "locally situated, self-regulating, and community-defined" (p. 20).

At this point readers should have a sense of how Aristotelian and current approaches to phronesis view the process leading to action that furthers the good. This ethical stance is aligned with the ambiguity, uncertainty, and undecidability that characterize the practical knowledge tradition mentioned above (Bacon, 2002; Schwandt, 2005). In the SLCE field, Butin's (2007) work shares some of its tenets, especially in his poststructural and antifoundational model of justice-learning. The practical judgments we make are not objective in the sense that modernist approaches (the scientific knowledge tradition) make of the term, but this does not mean that they are relativistic, self-serving, and irrational. When such judgments are enacted in the context of a cultivated practical wisdom, they are based on dialogical processes that bring in historical examples and experiences and on a reasoning that is substantive and attuned to the contingencies of an emergent situation. And we do it with others for whom those enactments matter.

The cultivation of practitioners follows on a path from normal to wise practice. Table 1 provides a bird's eye view of the process as the framework conceives it. Columns I and III present a summary comparison of the Bourdieusian and phronetic lenses. Column II, appropriately located between normal and wise practice, is about the spaces for and approaches to the desired transformation. Some of these have already been mentioned while others are presented below and in the concluding sections. The double reverse arrows serve as a reminder that the process is iterative and ongoing rather than linear.

Bourdieu's construct of habitus helps us consider people and their practices in terms of qualities and dispositions garnered through experiences in social settings or spaces they occupy more or less comfortably. Field and capital remind us of the settings and experiences that formed the person's habitus, the qualities and practices that emerge from it, and how changing aspects of the setting - field and capital - might support a transformation of the habitus. Phronesis provides the ethical lens, through the combined focus on virtues, situational ethics, and a much greater understanding of the process of 
Table 1

Habitus-Field-Capital, Phronesis, and Cultivating Practitioners in the Third Space

\begin{tabular}{|c|c|c|c|}
\hline & $\begin{array}{c}\text { I } \\
\text { WORLD AS IT IS } \\
\text { Normal Practice }\end{array}$ & $\begin{array}{c}\text { II } \\
\text { Third Space for } \\
\text { Cultivating Practitioners } \\
\longrightarrow \\
\leftarrow\end{array}$ & $\begin{array}{c}\text { III } \\
\text { POSSIBLE WORLD } \\
\text { Wise Practice }\end{array}$ \\
\hline Self-in-Context & $\begin{array}{l}\text { Dispositions \& orientations to } \\
\text { practice (habitus) embodied } \\
\text { through: } \\
\text { - experiences, } \\
\text { - in social settings (fields), } \\
\text { - using the resources (capitals) } \\
\text { of those settings. }\end{array}$ & \multirow{3}{*}{$\begin{array}{l}\text { Create multiple spaces } \\
\text { for ongoing cross-border } \\
\text { sensemaking, relationships, } \\
\text { and dialogue, that: } \\
\text { - Challenge AND support, } \\
\text { - Use inclusive reflective/ } \\
\text { sensemaking practices: } \\
\text { movement, art, games, } \\
\text { storytelling, emotions, } \\
\text { lifestories, } \\
\text { - Welcome discomfort \& } \\
\text { tensions, } \\
\text { - Search for and interrupt } \\
\text { oppressive normalcies, } \\
\text { - Change the rules of the } \\
\text { game and what counts as } \\
\text { capital, } \\
\text { - Reframe experiences/ } \\
\text { situations to seek cues for } \\
\text { human flourishing, } \\
\text { - Provide repeated } \\
\text { experiences that strengthen } \\
\text { new meanings/ways of } \\
\text { seeing, and related virtues, } \\
\text { - Evaluate micro and macro } \\
\text { practices to enact what is } \\
\text { "truly valuable." } \\
\end{array}$} & $\begin{array}{l}\text { Character qualities (virtues): } \\
\text { - cultivated in virtuous } \\
\text { communities, } \\
\text { - that motivate us to enact } \\
\text { human flourishing (the } \\
\text { good). } \\
\text { Who we are=What we see= } \\
\text { What we do }\end{array}$ \\
\hline Sensemaking & $\begin{array}{l}\text { Felt (embodied) sense - feel } \\
\text { for the game: } \\
\text { What are the rules of the } \\
\text { game? } \\
\text { What is my position in the } \\
\text { game, given the resources I } \\
\text { can access? } \\
\text { Is this game worth playing? }\end{array}$ & & $\begin{array}{l}\text { Perception and Deliberation: } \\
\text { - What are the stories? } \\
\text { - What is this situation about, } \\
\text { ethically/ morally/justly? Who } \\
\text { gains, who loses, through } \\
\text { what kind of power? } \\
\text { How can we move toward } \\
\text { 'flourishing' for all involved? }\end{array}$ \\
\hline Practices & $\begin{array}{l}\text { Strive for 'excellence' } \\
\text { according to the rules of the } \\
\text { game }\end{array}$ & & $\begin{array}{l}\text { Respond to the situation based } \\
\text { on wise judgment (personal \& } \\
\text { collective). }\end{array}$ \\
\hline
\end{tabular}

sensemaking and constructing the good than we get from Bourdieu. ${ }^{12}$ Sensemaking helps us understand how meanings are constructed and thus suggests that transformation can be fostered by directing the practitioner's attention to cues that can support different meaning constructions and wiser ways to respond in a practice situation.

The whole is a collective process that requires supportive social spaces or communities. Column II represents these spaces where new meanings, relationships and practices are cultivated, the habitus is potentially transformed, and the transformation is sustained. What is required here are perhaps not typical communities of practice but in-between spaces where we can show ourselves as vulnerable, less-than-perfect, uncertain beings who are motivated to engage in cross-border work. I call this a third space, which is a more fluid notion than community of practice and can take various forms, physical and symbolic, that support collaboration across borders and building communities of difference. Well-known examples include Jane Addams' Hull House (see Harkavy \& Puckett, 1994) and Belenky, Bond, and Weinstock's (1997) public homeplaces.

\section{Applying the Framework to the Vignettes}

Rather than continuing with an abstract discussion, let me return to the vignettes to illustrate the framework and its implications for teaching and learning practices and research. I use the first case primarily to illustrate habitus and normal and phronetic sensemaking. The second case mainly will illustrate sensemaking and enacting the good.

\section{Reflections of a Civically-Engaged Practitioner: Cynthia's Case}

The main learning tools used in this course were a partnership project, an autobiographical narrative, written critical incident reflections, the classroom as learning community, and a text (Keith 2015), which presents contexts, theory, and several cases (see Jacoby, 2015). The first assignment asked students to draw from their biography and identi- 
fy one personal and one work-related experience, both positive and negative, that shaped their understanding of 'partnership' and the orientation, values, qualities, capacities (resources), and motivations they were taking to the partnership project they were considering doing. Students also were asked to explain their choice of project and its focus, in light of this narrative. This assignment was designed to encourage students to begin to think of themselves and their projects along the lines of habitus-field-capital and phronetic character, without mentioning those terms.

Cynthia's autobiographical narrative revealed a highly reflective practitioner with considerable interest and experience in community work and strong values in the areas of youth empowerment, family engagement, and the ethics of collaboration. Instruments such as the Self-Assessment Matrix (SAM) would show her already on the 'expert' skill level (see Cress, Collier, \& Reitenauer, 2013). The students were encouraged to share their narratives in class and online, thus beginning to build spaces for dialogue, empathy, sensemaking, support, and change. The critical incident reflections were related to their partnership projects; students were reminded that anything that had "stayed with them" was not too small or insignificant to be considered a critical incident. The point was to have them focus on micropractices, everyday moments in which actions are taken or not taken, where what is normal and habitual might be challenged and new insights and practices might emerge. Three such moments are described in Keith (2010). At this point, the class had become fairly familiar with the framework presented above and students selectively used its thinking tools to make sense of their incidents. ${ }^{13}$

In her critical incident reflection, Cynthia revealed that her immediate reaction to the principal's comment about Gaby was emotional and visceral: "Instantly, I felt powerless. My heart sunk." Using the framework, these were important signs of a disturbance to the habitus, which is embodied. In this situation, Cynthia was interested in understanding how to act in response to this incident so as to remain aligned with her goals. She was also concerned about acting wisely, especially by being respectful of all involved and fostering capacities. She perceived a good fit between the thinking tools and her interest and so she began by focusing on her habitus and the logics of fields in which she was situated, personally and professionally.

Habitus. Starting with the habitus means that the practitioner considers who she is in the present situation in light of dispositions and orientations acquired through past and present experiences, both personal and professional. These include what she considers her qualities and capabilities, and also how her resources (capital) compare to those of others in the field and how they can help her achieve her goals. Moving toward a phronetic perspective would mean looking at the qualities (virtues) that came to the surface in the situation and deciding to cultivate and express, in supportive third spaces, those that would help her grow into the person she wanted to be. Recall that the phronetic practitioner's practice is an enactment of who she/he is and is motivated to become. For Cynthia, it meant being and enacting a thoughtful, empathetic, and competent professional capable of collaborating in creating a space for a genuine partnership between school and parents. There is no need to analyze why the principal's statement was so disturbing to Cynthia. The framework suggested she look at her past experiences, and she directed her attention to relations in her family (a field, with logics, capitals, and field positions from which practices are constructed) that seemed to be still influencing, through her habitus, her emotional reactions and her construction of the present situation.

Sensemaking. Recall that after the principal expressed her frustration with Gaby, Cynthia started to be bothered by things about Gaby that she had previously seen as assets. Cynthia made sense of her changed perception of Gaby by referencing both her family field (practices resulting from her mother being "caring but slightly invalidating" of her) and the education field of which the school is a part. The questions Cynthia asked could have led her to use sensemaking explicitly as a thinking tool but she did not go in that direction. We can extrapolate that there were tensions in her sensemaking that had to do with her personal and professional habitus: before Principal Davis' comment, Cynthia (as she asserts) had looked for cues that valorized Gaby's assets (gestures, language, clothing, and so on) as community cultural capital (Yosso, 2005). This was in line with the experiences in community organizing that made Cynthia valuable in her present work (i.e., positioned her well in this field). After the principal's comment, Cynthia was looking for cues that invalidated what she had previously constructed as capital, demoting it instead to expressions and behaviors that were, simply, 'inappropriate'. This was clearly a move from an assets to a deficit approach, which Cynthia was able to catch 'in the making,' by focusing on micropractices. The education field, of which the school is a subfield, along with capitals associated with the field, fosters a professional habitus that would influence in undetermined ways the principal's leadership practices and possibly her assessment of Gaby. This could happen at the same time that the 
principal was heartily committed to parental engagement, which included giving Cynthia the responsibility of creating a 'third space' for parent engagement. This in-between, border space joining school and community needed to have logics and capitals that might be different from the school's. But what would it be like?

Cynthia understood that going along with the principal's perception of deficit or her original perception of Gaby's assets had implications for her practice in the larger sense of the entire project. At this point, she became aware that her personal habitus was "clouding her vision." The "personal superhero" principal was not her "caring but slightly invalidating mother" and this relational dynamic need not negatively influence her perception of and actions toward Gaby. Continuing with phronesis, we see Cynthia begin to make sense of the situation in light of her own 'virtues', or qualities. As she saw it, her dilemma involved an excess of one virtue and a (temporary) deficit of another: respect for the principal had clouded her open-mindedness. Although she now "generally had a good handle ... on her validation-seeking attribute," it had temporarily caused her to be overly influenced by Principal Davis's assessment of Gaby, which then negatively impacted her understanding of and actions toward Gaby in the current situation.

Cynthia identified a tension between normalized expectations and discourses concerning professional behavior and her own desire to respect the qualities Gaby embodied and change the field's rules by valorizing Gaby's 'community capital'. The discourse of professionalism was an oppressive normalcy needing to be disturbed because it ran counter to an important good, culturally relevant practice. The community-oriented discourse resonated not only with Cynthia's values, but also with her extensive experiences and successes. Thus came a second troubling question: why was the principal she so admired partaking in this oppressive discourse?

Cynthia returned to the lens provided by her habitus and also to her other experiences at the school. She saw that Principal Davis was more complex than the binary construct she had initially projected onto her through the incident: "she does a good job of balancing seriousness with lightheartedness"; she was, at any rate, not perfect and Cynthia did not have to rely unduly on her for her own selfvalidation. Her respect for the principal was now balanced by a renewed and more nuanced understanding and commitment to community values and voice. She was a stronger and wiser practitioner because of the unsettling and turmoil caused by the incident and the sensemaking that ensued and was becoming a more trustworthy, respectful, competent CEP.

\section{Changing Course Elements in a Campus-School- Community Service-Learning Partnership}

The framework presented here was not used in designing the course, which was developed in 1998-1999. So in considering this vignette, the framework is used as an analytical tool rather than a thinking tool for mid-course correction in practice - which is how it could also be used. The course, which had at least seven sections each semester (though only one was involved in this partnership), was designed by a team that included experienced K-12 teachers in urban schools (where all the service experiences would take place) and College of Education faculty. This team bridged several divides in addition to campus-school, especially those of race, class, and culture, and became a wonderful cross-border CoP that lasted the entire seven years the core requirement was in place. Initially, course design was based on shared knowledge from three sources: (a) principles of good practice in servicelearning, including how to use service-learning to achieve K-12 curriculum objectives; (b) practicebased knowledge and theory on collaborations in the urban setting, which we described as "working with" rather than "doing to"; (c) interrupting seemingly normal behaviors that were actually oppressive ("interrupting oppressive normalcies"); and (d) active learning and student engagement.

Given that this was likely to be the first servicelearning course for most of the college students, expectations and assignments were clearly spelled out. A handout described the service-learning process for both groups of students. It included collaborating with community partners to identify possible projects; doing community-needs research; planning and implementing the project; reflecting in each phase; and presenting it to peers, teachers, and community partners. For the college students, each step in the service-learning process had corresponding assignments and their weights in the final grade. The main readings for the college students were a service-learning text edited by Wade (1997) and articles on urban education, structured social inequality, and African Americans in cities. Other short readings and handouts were collected and kept on the ready, to be distributed when 'hot' issues arose in class, in the teams, or at the sites.

Sensemaking. Sharon's emotional revelation that her students were becoming passive had an immediate effect on the team. She shared her feeling that many of the college students needed to change their attitudes and behaviors toward her students. It was 
true that they fooled around at times, but it was usually because they didn't understand something or felt they were not being listened to and their contributions were not taken seriously. There was also the fear of not being liked and judged negatively by strangers coming into their neighborhood. Not enough care was being taken to draw them into the teams and the process.

The college instructors trusted her judgment, recognized in themselves the felt-sense she had put into words, and accepted her evaluation. They were motivated to enact a good that had been on the table from the beginning - student engagement - expressing shock that they had actually participated in the enactment of its opposite. The coming summer was used to consider the issue further and devise changes to address the problem. We decided that we needed to understand how the students made sense of the curriculum, including the service-learning experience in the school and neighborhood, and so revisited their reflections looking for cues about needed changes and the levers of change at our disposal.

Habitus-field-capital and sensemaking. The reflections told us a story that can now be seen through the lens of habitus-field-capital. The college students were taking their academic habitus into the borderland where the service-learning project was symbolically located and we had not done enough to change the logics and capitals that would define a new field and thus potentially change the students' practices. What were normalcies in the education field had become oppressive in the service-learning field. To obviate this known possibility, instructors had stressed the importance of team collaboration during all phases of the project; but collaboration was not sufficiently valorized by what counts most in coursework: graded assignments. Many of the students (not all, because some were motivated to act collaboratively by their habitus) were making sense of the course in terms of completing tasks that counted toward the final grade (which also meant being a good student) and they had interpreted "service-learning project" to mean completion of a physical project. The instructors, on their part, thought they communicated that all the tasks counted because they were all part of the "service-learning process." But words and exhortations had only gone so far.

In the terms of the framework, there was great anxiety and a disturbance to the students' habitus caused by the new field and their not quite having a feel for the new game. Interestingly, even those who were most anxious about completing assignments and so had left their high school teammates in the dust, expressed regret in their final reflections about that aspect of their experience, and their desire for good relationships. That desire was a common theme and suggested strongly an opportunity to enact ethical practice: the desired relationships of caring, respect, and collaboration were the situational manifestation of human flourishing in this site. The college students did not want to act in disrespectful and uncaring ways, just as the high school students did not want to disengage and be passive. We needed to create spaces that would allow them all to move toward becoming virtuous practitioners.

Constructing and enacting the good. Once we read the cues, the resolution of the dilemma was close at hand: We would do more to cultivate students' qualities that supported engagement and communicate what this 'field' was about, through our ways of speaking and changes in handouts about assignments and grading rubrics. A new collaboration rubric showed that team building and collaboration had value and defined what competent enactment meant. We dialogued with the students about their position in the field, considering meanings and identities for the students in that in-between state - neither teachers nor students vis-à-vis their high-school partners. We invited them to reflect on their roles and use the experience to develop a greater understanding and empathy for those who would be their future students. We were thus inviting them symbolically to use this third space to cross from normal to wise practice. New reflection prompts also drew the students' attention to cues that would alert them to the presence or absence of student engagement.

By the next fall, a restructured service-learning process was in place that succeeded in positively changing student practices over the next two years. One change that resulted from the team's collective intelligence was having SLCE projects that would last a whole year: one year-long class of high school students would work with two different groups of college students (one in the fall and another one in the spring) on the same project. This contributed to a reversal of relationships, as the high school students took ownership of the projects and became guides for their college teammates, especially in the spring term. This change gave them new positions and capital in the field and the motivation to play the game. We also decided, and community partners agreed and continued to participate in, conducting all the projects within the school. Navigating this field in new ways also created more capital for the high-school students and changed many teachers' perceptions of them.

\section{Contributions of the Framework}

Before briefly summarizing below what the framework suggests concerning teaching and re- 
search, I will start by highlighting some of what I see as its broad advantages. First, the framework is about practice. If this sounds too simple, we can recall that Bacon's community partners considered learning as competent practice while faculty considered learning as best expressed in words. An argument could be made that moving toward practice theory constitutes a move toward bridging the campus-community divide, as this perspective is potentially close to the questions and interests of community partners.

A second advantage is that the framework constitutes a comprehensive approach to ethical action. The more conventional approach is to identify principles and codes of ethics that are typically stated in terms of rights and responsibilities (or obligations) of the parties involved. A service-learning ethics code developed by Chapdelaine, Ruiz, Warchal, and Wells (2005) describes a common obligation termed competence. As an example, a competent faculty member plans the service-learning experience according to named quality standards. The book includes hypothetical dilemmas and decision-making guides that can be used in professional development sessions. The practitioner is then tasked with considering those rights and responsibilities that are relevant and applicable in any given situation. For a practitioner at this stage, it is a good start.

Phronesis as ethical practice provides a more holistic way of being ethical and engaging in ethical action. It includes, as we have seen, the whole area of perception, whereby one looks at a situation to see cues about possibilities it holds for human flourishing. As Kreber (2016) maintains, self-cultivation is also essential, as it is the inner aspect of civic mindedness. There should be conversations about what constitutes flourishing in the situation, of course, but the idea suggests a wider arena that encompasses more subtle aspects of practice, is more positively constituted than rights and responsibilities, and is possibly more attuned to issues of power. The essence of ethics in this approach is that its source is the character, habitus, heart of the practitioner-in-context, meaning that there need to be experiences and communities for support and further cultivation. Organizations will still need ethical codes such as the one mentioned above, but we also need to see ethics as the cultivation of empathy, the heart, and other qualities to be expressed through one's practices. And so we need other types of community spaces.

A third contribution is in the area of sensemaking, particularly those aspects that have to do with making meanings. Imagination, stories, and creativity are all involved in constructing plausible, multilayered, inclusive narratives about practice situations and the possibilities for human flourishing they hold and how they can be actualized through practical wisdom. Meaning making is a collective process; it must involve others because we need collective intelligence to create meanings but also because we cannot sustain meanings alone. This is a different way of understanding what happens when a group comes together and talks, with facilitation from a colleague, teacher, staff or other person. Again, invoking Bacon's community partners, in the academy we are used to interpreting the activity (and using the language) as a group discussion through which each participant may learn something. As these community partners' comments suggest, more valuable than a discussion and individual learning is seeing and engaging the process as a collective practice of meaning making leading to collective learning and action (praxis) and relationship building. As Cantrell and Sharpe (2015) use the process, the group can be guided to make meanings that include broader and more ethical understandings that are not deficit based, are more complex, include more perspectives, and broaden meaning horizons. Thinking of a servicelearning group in this way opens up more modalities for participation, especially storytelling.

\section{Implications for Teaching and Research}

The vignettes have already presented some of the main implications of the framework for both and may have suggested, along with the above, some fruitful research agendas. This means, I hope, that the sketches provided below are sufficient for the time being.

\section{Reflection}

Following on the work of Boler (1999) and Zembylas (2007) on emotions, power and education, and pedagogies of discomfort, a fairly recent strand in the SLCE literature looks at emotions in teaching and learning, asking how they should enter the reflection process. Felten, Gilchrist, and Darby (2006) suggest a redefinition of service-learning reflection to include "the interplay of emotion and cognition" (p. 42). This redefinition provides a rationale for inclusive reflective practices (many in use by educators, especially in K-12 settings) that make room for insights and learning that involve emotions, as they emerge through the body (dance, movement, Theater of the Oppressed), art, poetry, storytelling, narratives, and even games (see Noyes, Darby, \& Leupold, 2015). Active reflection practices used in intergroup dialogues provide additional insights and examples for teaching practice that specifical- 
ly address multiple categories of diversity (Gurin, Nagda, \& Zúñiga, 2013).

This research is relevant because, as we saw especially from the first vignette, disturbances of the habitus are visceral and emotional experiences. Not every emotional expression is the result of this kind of disturbance, but attention to the emotions, how they can be enmeshed in games of power, and how they can lead back to the dispositions and orientations of the habitus are good starting places for this sort of reflection. Given that the habitus is constituted through experiences, it can also be shifted through a reframing of those experiences and additional experiences that support the shift. ${ }^{14}$ Reframing experiences can be supported by sharing them with a group, through various modalities as appropriate to the group: a narrative, artwork, movement, as well as writing, including creative writing, a story circle. This exercise is not about explaining how one's habitus is linked to one's prior experiences; it is a way of building connections and relationships through the sharing of experiences and the group 'talk back' that follows.

\section{Course and Program Design}

Understanding the relatedness of practice, practitioner, and practice situation means that changes in practices can result in changes in the practitioner. This is also true of other elements, which are interconnected. Looking at a course through the lens of habitus-field-capital and phronesis suggests ways to support desired practices and challenge undesirable ones. The issue, broadly, is what counts as resources and rewards and how they are used to excel in a setting that is conceived of as a game. Generally, assignments and their assessment are the main tools available for this purpose. There is no reason to revisit how change in collaboration practices was created in the second vignette and so let me comment on two additional points. First, we should take special steps to consider how students and participants will make sense of the assessments. Normal ways of making sense of pedagogical tools in the traditional field (the campus) will carry over into a border, in-between field (the school); thus more feedback, dialogue, and confirming experiences than usual are needed to enshrine new meanings.

The second point is to ensure that assessments that matter are also aligned with course goals in all important areas - academic, developmental, and partnership relations. It is often difficult, given the logic of the academic field, to include nonacademic learning in one's assignments as part of a grading schema - and what is not graded does not count for much unless the students' intrinsic motivation is engaged. The habitus of students as well as administrators and faculty is affected by this logic, as students' dispositions are to accept (and use their capital to succeed in) being graded on academic contents, but not in the other areas mentioned. This point supports the importance of program planning at the campus level, connecting academic, student development, and other areas (Bringle et al., 2011).

The second vignette revealed a strong desire for connection and relationships among the students. Recalling that habitus (and virtuous character) is formed in communities, through experiences with others, strong relationships are important for crossing borders and being invited into different fields where transformations can begin and be sustained. This suggests that learning and changing can happen without the intervention of structured reflection, simply by being for an extended time, and not just as a spectator, in the company of Others. According to practice fields and phronesis, knowledge is a dynamic achievement that occurs as people interact with their environments. As Kassam (2010) puts it, "it lies not in the heads of professors but in the world that they point out to students" (p. 209). This realization calls for a sense of humility on the part of campus-based practitioners. Kiely's (2005) research also points to what he terms connecting, and the potential transformation that comes not through rational reflection but through concrete experiences interacting with concrete human beings who were Other prior to the experience. This is an important finding, as such emotional and visceral human learning may play a role in keeping high-dissonance experiences alive in us, to continue their transformative work long after they happened.

\section{Research}

It should be clear by now, based on the proposed framework, that my value preference is for research that examines and changes practices in ways that support our capacity to pursue ethical goals, as defined phronetically. That this is not the only legitimate goal for research goes without saying; but it is one that should be of considerable importance for researchers who are committed to democratic engagement in a field that is practice-based. Research based on practice theory, as presented here, lends itself to the detailed examination of micropractices and processes that can result in 'small' positive changes in one's practices (as in Cynthia's case) or 'larger' changes in the ways practices are organized (e.g., a course, an organization, a 'system'). Of course, if we agree that these practices are all connected, then the notion of 'small' and 'larger' make 
less sense. Nonetheless, the point of entry into the research matters.

If I read them correctly, Giles and Eyler (2013) point to a gap and a need for research in SLCE that could be addressed through approaches informed by practice theory. They do this from the foundation of their extensive historical knowledge of the field and in the context of more recent contributions (the article is a book review essay of two-volumes on service-learning research edited by Clayton, Bringle and Hatcher, 2013). Giles and Eyler remark that an important way to strengthen research, given the state of the field, is to assess how key elements of service-learning practice are implemented. A starting point should be the "deconstruction of the service-learning experience itself . . . [to] provide descriptions of some of the varied ways these experience are developed, students are prepared, the sites are managed and monitored, and the reflective processes are designed" (p. 56). Among the research questions they offer are,

How often and how does the service-learning class actually incorporate a process that genuinely creates a project that is mutually beneficial for the students and community members?" What does a placement that is mutually designed and beneficial . . look like?" (pp. 55-56)

Given my own orientation, research should go further than descriptions, although this is an essential starting point. The problem is that, as I see it, it is not possible to offer impartial and objective descriptions of practice. Thus, if one is interested in 'mutuality,' issues that relate to power and power sharing should make more than a cursory appearance: One would have to describe the practice at least by including that lens. Who is participating in framing the questions, and later, interpreting the data? Whose voices are at the table? And, returning to the topic of this article, how is the capacity of the practitioners to see and surface these issues, through collaboration and dialogue, being cultivated? These, for me, are essential questions - although I do not know that Giles and Eyler and authors mentioned and included in the collection are not also equally concerned about them.

This brings me to the next possible contribution, which comes from the field of planning, originally, and more generally, the policy field. My interest in phronetic practice theory began when reading a book by Flyvbjerg (2001), Making Social Science Matter. Developing the theoretical supports and coining the notion of applied phronesis, he argued for understanding the virtuoso practitioner as a different sort of knower, one whose decisions are based not on the application of generalizable scientific data but on lived (and perhaps, to an extent, vicarious) experience in and with a multiplicity of concrete cases and the ability to use them wisely to grasp what mattered in the situation at hand. Flyvbjerg made a cogent argument that the social sciences had a vital contribution to make in this regard and that it would be best made by producing knowledge in support of wise practice. This meant taking a new look at a rather maligned method: the case study. Applied phronesis would provide the tools for the researcher-practitioner to enact an ethical practice that "challenges power relations and brings about positive social change" (Flyvbjerg, Landman, \& Schram, 2016, p. 3).

Since that time, researchers in this vein have conducted extensive research at times involving very large case studies. Examination of these cases led them to identify an approach that supports critical policy analysis and the ability to induce significant change. It centers on identifying tension points, or "power relations that are particularly susceptible to problematization and thus change, because they are fraught with dubious practices, contestable knowledge and potential conflict" (Flyvbjerg, Landman, \& Schram, 2016, p. 3, emphasis in original).

My point in writing this is twofold. The first is to note that case studies do not have to remain in splendid isolation. We can develop ways to examine them collectively, so as to uncover critical and actionable information such as indicated above. I have not thought about this sufficiently to produce answers or even interesting questions out of my thinking hat, but it strikes me that it is an avenue worth pursuing. Practice theory, as presented here by others and me, clearly provides conceptual frameworks that can be used to research and improve practice. The second point is that our goal could be larger and, perhaps, more virtuous: examining qualitative studies collectively might unearth tension points or their equivalent for SLCE, pointing to power relations and ways to initiate systemic changes in the field.

The field of practice theory and related research is still evolving and so are its methods. Phronetic practice researchers can, however, make use of established traditions such as sociological phenomenology (especially standpoint theories), critical ethnography, and participatory action research, with equally well-established methods and research agendas. Participatory action research, especially of the critical variety, involves participants in empowering research and action on issues that matter to them. The method is used by critical urban researchers and community organizers, among others (see Cammarota \& Fine, 2008; Kemmis, 
2009; Torre, Fine, Stoudt, \& Fox, 2012). Among many interesting example is Fuentes' (2011) work with the VOCES Latinas (Latina/o Voices) Project in a Northern California city. Using critical ethnography along with critical participatory action research, Fuentes provides a detailed account of a process she terms practicing citizenship that built community voice and knowledge among Latino immigrant parents involved in their children's high school and led to transformation in public and personal practices.

Sociological phenomenology focuses on the everyday world and is concerned with the social construction of meanings, particularly the shared understandings that we tend to take for granted. Standpoint theories are especially interesting for us because they focus on the shared meanings and knowledge that emerge from the positionality of a given oppressed and disadvantaged group. For Hill Collins (2000), the search for the silenced voices and meanings of African American women necessarily straddles social, narrative, and historical fields. Using this lens for the standpoint of women, Smith $(1987,2005)$ developed notions such as 'relations of ruling' and a method she terms institutional ethnography. These are only a few of the methods that are well-developed and have yielded strong and interesting research.

\section{Final Self-Reflection}

I conclude with a brief reflection about my own process in writing this article. Writing and revising and trying to pay attention to language, thought, bodily sensing, and so on, and to 'getting it right' (or not) has made me quite conscious of the radical departure practice theory constitutes. Nicolini (2012) calls it a Copernican revolution and I now feel he may well be correct. If I accept that practices are inscribed in the body and that my own habitus as an academic was nurtured and cultivated in the context of ecologies and architectures of practices (and academic communities) that value the analytical, rational, and individual, I must also accept that my presentation here can only be partial at best, that a practice approach needs to be inscribed in my body through much more experience, more dialogue, and collective intelligence. As I reviewed my writing, I constantly had to remind myself of the counternormative nature of practice theory and of my own embeddedness, my critical mind notwithstanding, in the scientific/analytical tradition that kept creeping back unnoticed. Changing embodied practices is a work in progress. I thought I had taken a significant step forward when I imagined and felt myself standing in the classic river, conscious that, like experience, like practice, the river is everflowing, never the same. Then I realized that the metaphor applied to me as well: The river is different each time, and so am I. That's much harder to grasp.

\section{Notes}

${ }^{1}$ I am deeply grateful for conversations and thoughtful reading and suggestions made by Nora Pillard Reynolds, Martha Carey, Cynthia Jones, and Eric Hartman. To the anonymous reviewers of earlier versions of my writing, my humble thanks for your exemplary qualities in critical peer review.

${ }_{2}^{2}$ Additional features include embodiment, material mediation, relationality, situatedness, emergence, and co-construction. For a brief summary and explanation, see Boud, 2012.

${ }^{3}$ This is a shortened definition of critical incident I provide my students: It is "an experience in which you were involved, centrally or marginally, that stayed with you. The experience may bring up emotions and issues that are not easy to resolve. It may involve unease and uncertainty - about what to feel, how to act, and so on. It made you 'stop and think'. Because it stayed with you, it has the potential to cause a shift - small or large - about who you are, where you are going, and how you see and act in the world."

${ }^{4}$ The full cases are presented in Keith \& Jones, 2015 (Cynthia's case) and Keith, Hafiz, \& Peterson, 2015 (urban partnership case). In my teaching, I encourage students to "find the theory," starting by considering their experiences and the concepts (or thinking tools) in light of each other.

${ }^{5}$ These are components of the framework, which is represented in Table 1.

${ }^{6}$ Reynolds' (2014) research shows that situational ethics is important even in this realm: The community members in her study explained that being a 'laboratory' for a particular practice was not problematic per se; what was problematic was the absence of information and dialogue around the use of practices that were experimental.

${ }^{7}$ This is the import of the well-known work on language by anthropologist William Labov (2001), and writings on the culture of power in schooling by education researcher Lisa Delpit (1995). Keith (1997/2013) discusses these issues with specific reference to service learning.

${ }^{8}$ This point was made by Suad Islam with reference to a campus-community case in which she was a community representative. The (well-meaning) campus partners would bring crudités such as raw broccoli, celery, with dips to evening meetings. For community partners who came straight from work, 
this was frustratingly "not dinner" (cited in Keith et al, 2003).

${ }^{9}$ For more studies, both theoretical and empirical, involving Bourdieu's habitus and interrupting habitus, see Crossley (2013), Horvat \& Davis (2011), Malandra (2007), and Reay (2004). For cultural capital, see Lareau \& Calarco (2012). For the intersection of field and habitus, see Leander (2009).

${ }^{10}$ Following the work of Dreyfus and Dreyfus, Flyvbjerg (2001) points out that novice practitioners do indeed need rules, which become less useful as they move toward becoming competent and expert performers. Performance by experts involves an embodied felt-sense of what to do that comes from experience with manifold concrete cases.

${ }^{11}$ What Nicolini (2012) says about habitus applies here as well: Agency in practice theory is primarily about ways of being (and felt-sense) and acting, not ways of thinking.

12 Habitus does include schemes of perception that organize reality and experiences and the meanings persons attribute to experiences. For instance, in Distinction, Bourdieu (1984) considers class-based constructions of a photograph of an old woman's hands. Working-class respondents comment on her arthritis and the pain she must feel, whereas more privileged and thus more socially distant respondents comment on the hands as symbolic of work and the deforming effects of poverty. Both views are appropriate in the respective fields but through symbolic capital the latter may be constructed as more enlightened! Bourdieu locates such comments in the context of cultural capital rather than considering the process of perception as such.

${ }^{13}$ There is always a question about whether the thinking tools presented in a community-based course will be appropriate to the emerging issues and interests of the students and there was no requirement that the students use this particular framework. Most students did, however, possibly because they saw it constituting capital in the course. I conveyed the message in several ways, but "saying it isn't so" is not enough! The syllabus for the course is available on the Philadelphia Higher Education Network for Neighborhood Development (PHENND) website. See http://phennd.org/ resources/syllabi/

${ }^{14}$ Mitchell et al's (2015) research on the lasting effects of undergraduate service-learning experiences strongly suggests that a design involving repeated experiences over time (e.g., one course a semester over several years) is more likely to produce such effects than shorter experiences. Putting this information through the lens of the framework supports the notion that the habitus-transformation process needs to be extended. A similar point can be made through a reframing of Warren, Park and Tieken (2016) along these lines.

\section{References}

Argyris, C. (1991, May-June). Teaching smart people how to learn. Harvard Business Review, 99-109.

Bacon, N. (2002). Differences in faculty and community partners' theories of learning. Michigan Journal of Community Service Learning, 9(1), 34-44.

Baehr, J. (2013, January 2). Educating for intellectual character. Retrieved from Harvard Education Publishing Group: http://hepg.org/blog/educating-forintellectual-character

Barker, D. W., Allen, A. D., Robinson, A., Sulimani, F., VanderVeen, Z., \& Walker, D. M. (2011). Research on civic capacity: An analysis of Kettering literature and related scholarship. Kettering Foundation Working Paper 2011-1. Retrieved from http://kettering.org/ wp-content/uploads/Barker-Civic-Capacity-Final-KFWP-2011-011.pdf.

Belenky, M.F., Bond, L.A., \& Weinstock, J.S. (1997). A tradition that has no name: Nurturing the development of people, families, and communities. New York: Basic.

Bheekie, A., \& van Huyssteen, M. (2015). Teaching, learning, and becoming mindful of discomfort. International Journal of Research on Service-Learning and Civic Engagement, 3(1). Retrieved from http://jour nals.sfu.ca/iarslce

Biesta, G. (2007). Why 'what works' won't work: Evidence-based practice and the democratic deficit in educational research. Educational Theory, 57(1), 122. https://doi.org/10.1111/j.1741-5446.2006.00241.x

Boler, M. (1999). Feeling power: Emotions and education. New York: Routledge.

Boud, D. (2012). Problematising practice-based education. In J. Higgs, R. Barnett, S. Billett, M. Hutchings, $\&$ F. Trede (Eds.), Practice-based education: Perspectives and strategies (pp. 55-69). Rotterdam: Sense Publishers. https://doi.org/10.1007/978-94-6209-1283_5

Boud, D., \& Brew, A. (2013). Reconceptualising academic work as professional practice: Implications for academic development. International Journal for Academic Development, 18(3), 208-221. doi:10.1080/136 0144X.2012.671771.

Bourdieu, P. (1977). Outline of a theory of practice. (R. Nice, Trans.) Cambridge, UK: Cambridge University Press. https://doi.org/10.1017/CBO9780511812507

Bourdieu, P. (1984). Distinction. Cambridge, MA: Harvard University Press. https://doi.org/10.1007/ BF00174048

Bourdieu, P. (1985). The social space and the genesis of groups. Theory and Society, 14(6), 723-744. https:// doi.org/10.2307/202060 
Bourdieu, P. (1989). Social space and symbolic power. Sociological Theory, 7(1), 14-25.

Bourdieu, P., \& Passeron, J.-C. (1990). Reproduction in education, society, and culture. Thousand Oaks, CA: Sage.

Boyte, H. C., \& Fretz, E. (2010). Civic professionalism. Journal of Higher Education Outreach and Engagement, 14(2), 67-90.

Bringle, R. G., Studer, M., Wilson, J., Clayton, P. H., \& Steinberg, K. S. (2011). Designing programs with a purpose: To promote civic engagement for life. Journal of Academic Ethics, 9, 149-164. https://doi. org/10.1007/s10805-011-9135-2

Butin, D. W. (2007). Justice-learning: Servicelearning as justice-oriented education. Equity \& Excellence in Education, 40, 177-183. doi:10.1080/10665680701246492.

Cammarota, J., \& Fine, M. (Eds.). (2008). Revolutionizing education: Youth participatory action research in motion. New York: Routledge.

Cantrell, D., \& Sharpe, K. (2015). Practicing practical wisdom. Social Science Research Network. Retrieved from http://ssrn.com/abstract=2575945. https://doi. org/10.2139/ssrn. 2575945

Carrington, S. B., Deppeler, J., \& Moss, J. (2010). Cultivating teachers' beliefs, knowledge and skills for leading change in schools. Australian Journal of Teacher Education, 35(1), 1-13. Retrieved from http:// eprints.qut.edu.au/32963/1/c32963.pdf. https://doi. org/10.14221/ajte.2010v35n1.1

Caterino, B., \& Schram, S. F. (2006). Introduction: Reframing the debate. In S. Schram \& B. Caterino (Eds.), Making political science matter: Debating knowledge, research, and method (pp. 1-13). New York: New York University Press.

Chapdelaine, A., Ruiz, A., Warchal, J., \& Wells, C. (2005). Service learning code of ethics. Bolton, MA: Anker.

Clayton, P. H., Bringle, R. G., \& Hatcher, J. A. (Eds.). (2013). Research on service learning: Conceptual frameworks and assessment (Vol. 2A \& 2B). Sterling, VA: Stylus.

Collins, P. H. (2000). Black feminist thought: Knowledge, consciousness and the politics of empowerment (2nd ed.). New York: Routledge.

Coulter, D., \& Wiens, J. R. (2002). Educational judgment: Linking the actor and the spectator. Educational Researcher, 31(4), 15-25. https://doi. org/10.3102/0013189X031004015

Cress, C. M., Collier, P. J., Reitenauer, V. L., \& Associates. (2013). Learning through serving: A student guidebook for service-learning and civic engagement across academic disciplines and cultural communities (2nd ed.). Sterling, VA: Stylus.

Crossley, N. (2013). Pierre Bourdieu's habitus. In T. Sparrow \& A. Hutchinson (Eds.), A history of habit: From Aristotle to Bourdieu (pp. 291-307). Lanham, MD: Lexington.

Darling-Hammond, L., Chung Wei, R., Andree, A., Richardson, N., \& Orphanos, S. (2009). Professional learning in the learning profession: A status report on teacher development in the United States and abroad. Dallas, TX: National Staff Development Council and School Redesign Network.

Delpit, L. (1995). Other people's children: Cultural conflict in the classroom. New York: New Press.

Dostilio, L. D., \& McReynolds, M. (2015). Community engagement professionals in the circle of servicelearning and the greater civic enterprise. Michigan Journal of Community Service Learning, 22(1), 113-116. Retrieved from https://slce-fdp.org/essays/ thought-pieces/dostilio-mcreynolds/dostilio-mcreyn olds-full-text/

Dreese, D., Dutton, T. A., Neumeier, B., \& Wilkey, C. (2008). A people's history: Teaching an urban neighborhood as a place of social empowerment. transFORMATIONS, 19(1), 138-158.

Dunne, J., \& Pendlebury, S. (2003). Practical reason. In N. Blake, P. Smeyers, R. Smith, \& P. Standish (Eds.), Blackwell guide to the philosophy of education (pp. 194-212). Malden, MA: Blackwell. https://doi. org/10.1002/9780470996294.ch12

Eyler, J. (2002). Reflection: Linking service and learning - Linking students and communities. Journal of Social Issues, 58(3), 517-534. https://doi.org/10.1111/15404560.00274

Fahey, G. M. (2002, June 1). The idea of the good in John Dewey and Aristotle. Essays in Philosophy, 3(2), Article 10.

Farnsworth, V. (2010). Concptualizing identity, learning and social justice in community-based learning. Teaching and Teacher Education, 26, 1481-1489. doi:10.1016/j.tate.2010.06.006

Felman, S. (1982). Psychoanalysis and education: Teaching terminable and interminable. Yale French Studies, 63, 21-44. https://doi.org/10.2307/2929829

Felten, P., \& Clayton, P. H. (2011). Service Learning. New Directions for Teaching and Learning, 128, 7584. doi: $10.1002 / \mathrm{tl} .470$

Felten, P., Gilchrist, L. Z., \& Darby, A. (2006). Emotions and earning: Feeling our way toward a new theory of reflection in service-learning. Michigan Journal of Community Service Learning, 12(2), 38-46.

Finley, A. (2011). Civic learning and democratic engagement: A review of the literature on civic engagement in post-secondary education. Association of American Colleges and Universities. Retrieved from http://www.uwec.edu/Usenate/SenateCommittees/AP C/1213/121030LiteratureReviewCivicEngagement.pdf

Flyvbjerg, B. (2001). Making social science matter: Why social inquiry fails and how it can succeed again. Cambridge, UK: Cambridge University Press. https://doi. org/10.1017/CBO9780511810503

Flyvbjerg, B., Landman, T., \& Schram, S. F. (2016, forthcoming). Tension points: Learning to make social science matter. Critical Policy Studies. Available at Social Science Research Network, http://ssrn.com/ abstract $=2721321$

Follman, J. (2015). An overlooked lens: Applying structuration theory, actor-network theory, and theories of space to service-learning. International Journal of 
Research on Service-Learning and Community Engagement, 3(1). Retrieved from http://journals.sfu.ca/ iarslce

Foucault, M. (1977/1995). Discipline and punish: The birth of the prison. (A. Sheridan, Trans.). New York:Vintage.

Fuentes, E. H. (2011). Practicing citizenship: Latino parents broadening notions of citizenship through participatory research. Latino Studies, 9(4), 396-414. https:// doi.org/10.1057/lst.2011.48

Gherardi, S. (2008). Situated knowledge and situated action: What do practice-based studies promise? In D. Barry \& H. Hansen (Eds.), The SAGE handbook of new approaches in management and organization (pp. 516-525). Thousand Oaks, CA: Sage. https://doi. org/10.4135/9781849200394.n89

Gherardi, S. (2009). Introduction: The critical power of the 'practice lens'. Management Studies, 40(2), 115128. https://doi.org/10.1177/1350507608101225

Giles, D. E., \& Eyler, J. (2013). Review essay: The endless quest for scholarly respectability in servicelearning research. Michigan Journal of Community Service Learning, 20(1), 53-64.

Glass, C. R., Doberneck, D. M., \& Schweitzer, J. H. (2011). Unpacking faculty engagement: The types of activities faculty members report as publicly engaged scholarship during promotion and tenure. Journal of Higher Education Outreach and Engagement, 15(1), 7-30.

Gurin, P., Nagda, B. A., \& Zúñiga, X. (2013). Dialogues across difference: Practice, theory, and research on intergroup dialogue. New York: Russell Sage Foundation.

Harkavy, I. \& Puckett, J. (1994). Lessons from Hull House for the contemporary urban university. Social Service Review, 299-321. https://doi.org/10.1086/604061

Hatcher, J. A. (2008). The public role of professionals: Developing and evaluating the civic-minded professional scale. Ph.D. Dissertation, Indiana University. Retrieved from https://scholarworks.iupui.edu/han dle/1805/1703

Horvat, E. M., \& Davis, J. E. (2011). Schools as sites for transformation: Exploring the contribution of habitus. Youth \& Society, 43(1), 142-170. https://doi. org/10.1177/0044118X09358846

Hoyt, L. (2010). A city-campus engagement theory from, and for, practice. Michigan Journal of Community Service Learning, 17(1), 75-88.

Hursthouse, R. (1999). On virtue ethics. Oxford, UK: Oxford University Press.

Jacoby, B. (2015). Taking campus-community partnerships to the next level through border crossing and democratic engagement. Michigan Journal of Community Service Learning, 22(1), 140-146.

Jagla, V. M., Lukenchuk, A., \& Price, T. A. (2010). Imagining a better world: Service-learning as benefit to teacher Eeducation. National Louis University Digital Commons. Retrieved from National Louis University Digital Commons, Faculty Publications: http://digital commons.nl.edu/faculty_publications/72
Kassam, K.-A. (2010). Practical wisdom and ethical awareness through student experiences of development. Development in Practice, 20(2), 205-218. https://doi.org/10.1080/09614520903564207

Keith, N. Z. (1997/2013). Doing service projects in urban settings. In A. S. Waterman (Ed.), Service learning: Applications from the research (pp. 127-149). New York: Psychology Press.

Keith, N. Z. (2010). Getting beyond anaemic love: From the pedagogy of cordial relations to a pedagogy for difference. Journal of Curriculum Studies, 1-34 (First published on 07 December 2009). https://doi. org/10.1080/00220270903296518

Keith, N. Z. (2015). Engaging in social partnerships: Democratic practices for campus-community partnerships. New York: Routledge.

Keith, N. Z., Cavanaugh, C., Islam, S., Hafiz, F., Mather, K., \& Soler, J. (2003, March 1). Partnerships as new ground; Between private enterprise and democratic possibilities. Practitioner Keynote, Ethnography in Education Research Forum, University of Pennsylvania. Philadelphia, PA.

Keith, N. Z., Hafiz, F., \& Peterson, J. (2015). From normal to wiser practice in a high school, community and university service-learning partnership. In N. Z. Keith, Engaging in social partnerships: Democratic practices for campus-community partnerships (pp. 133-160). New York: Routledge.

Keith, N., \& Jones, C. (2015, November 17). Becoming practitioners of democratic civic engagement. Boston: International Association for Research on Service Learning and Civic Engagement. Retrieved from https://www.academia.edu/18665457/Becom ing_Practitioners_of_Democratic_Civic_Engagement

Kemmis, S. (2009). Action research as a practice-changing practice. Educational Action Research, 17(3), 463474. https://doi.org/10.1080/09650790903093284

Kemmis, S., Wilkinson, J., Edwards-Groves, C., Hardy, I., Grootenboer, P., \& Bristol, L. (2014). Changing practices, changing education: . Singapore: Springer Science+Business Media. https://doi.org/10.1007/978981-4560-47-4

Kiely, R. (2005). A transformative learning model for service-learning: A longitudinal case study. Michigan Journal of Community Service Learning, 12(5), 5-22.

King, R. (2015). Virtue ethics: Foundation for civic engagement and service-learning. In O. Delano-Oriaran, M. W. Penick-Parks, \& S. Fondrie (Eds.), SAGE sourcebook of service-learning and civic engagement (pp. 17-22). Los Angeles: Sage. https://doi. org/10.4135/9781483346625.n9

Kinsella, E. A., \& Pitman, A. (Eds.). (2012). Phronesis as professional knowledge: Practical wisdom in the professions. Rotterdam \& Boston: Sense. https://doi. org/10.1007/978-94-6091-731-8

Kreber, C. (2016). Educating for civic-mindedness: Nurturing authentic professional identities through transformative higher education. New York: Routledge.

Labov, W. (2001). The anatomy of style-shifting. In P. 
Eckert \& J. R. Rickford (Eds.), Style and sociolinguistic variation (pp. 85-108). Cambridge: Cambridge University Press.

Ladson-Billings, G. (2004). Culture versus citizenship: The challenge of racialized citizenship in the United States. In J. Banks (Ed.), Diversity and citizenship education: Global perspectives (pp. 99-126). San Francisco: Jossey-Bass.

Lareau, A., \& Calarco, J. M. (2012). Class, cultural capital, and institutions: The case of families and schools. In S. T. Fiske \& H. R. Markus (Eds.), Facing social class: How societal rank influences interaction (pp. 61-86). New York: Russell Sage.

Leander, A. (2009, November 30). Habitus and field. Working paper. Copenhagen Business School: Department of Intercultural Communication and Management. Retrieved from http://openarchive.cbs.dk/ handle/10398/7966

Lee, A., Dunston, R., \& Fowler, C. (2012). Seeing is believing: An embodied pedagogy of 'doing partnership' in child and family health. In P. Hager, A. Lee, \& A. Reich (Eds.), Practice, learning and change: Practicetheory perspectives (pp. 267-276). Dordrecht: Springer Science+Business Media.

Lukenchuk, A., Jagla, V. M., \& Price, T. A. (2013). Critical discourse analysis of service-learning perspectives and models: Transforming teacher education. In V. A. Jagla, J. A. Erickson, \& A. S. Tinkler (Eds.), Transforming teacher education through service-learning (pp. 51-69). Charlotte, NC: Information Age.

Macintyre Latta, M., \& Wunder, S. (Eds.). (2012). Placing practitioner knowledge at the center of teacher education: Rethinking the policies and practices of the education doctorate. Charlotte, NC: Information Age.

Malandra, K. (2007). Interrupting habitus and community-based arts: Pedagogical efficacy in a university/community collaboration. (Order No. 3268170, Temple University). ProQuest Dissertations and Theses, 287. Retrieved from http://search.proquest.com/ docview/304827516? accountid=14270 (304827516)

Mathews, D. (2004, April 7). Six democratic practices. Kettering Foundation working paper draft. Retrieved from http://www.publicpolicycenter.hawaii.edu/documents/PPC2Keynote_001.pdf

McGee, M. C. (1998). Phronesis in the Gadamer versus Habermas debates. In J. M. Sloop \& J. P. McDaniel (Eds.), Judgment calls: Rhetoric, politics, and indeterminacy (pp. 13-41). Boulder, CO: Westview.

McMillan, J. (2011a). What happens when the university meets the community? Service learning, boundary work, and boundary workers. Teaching in Higher Education, 16(5), 553-564. doi:10.1080/13562517.2011.580839.

McMillan, J. (2011b). Boundary workers and their importance to community-university partnerships. Metropolitan Universities, 22(2), 106-120. Retrieved from https://journals.iupui.edu/index.php/muj/article/ viewFile/20476/20076.

McReynolds, M. R. (2015). Developing practitionerscholars for the future of community engagement. In O. Delano-Oriaran, M. Penick-Parks, \& S. Fondrie
(Eds.), The SAGE sourcebook of service learning and civic engagement (pp. 3-9). Thousand Oaks, CA: Sage. https://doi.org/10.4135/9781483346625.n7

McReynolds, M., \& Shields, E. (Eds.). (2015). Diving deep in community engagement: A model for professional development. Des Moines, IA: Iowa Campus Compact.

Mitchell, T. (2014). How service learning enacts social justice sensemaking. Journal of Critical Thought and Praxis, 2(2), Article 6.

Mitchell, T., Richard, F. I., Battistoni, R. M., Rost-Banik, C., Netz, R., \& Zakoske, C. (2015). Reflective practice that persists: Connections between reflection in service learning programs and in current life. Michigan Journal of Community Service Learning, 21(2), 49-63.

Musil, C. M. (2009). Educating students for personal and social responsibility: The civic learning spiral. In B. Jacoby (Ed.), Civic engagement in higher education: Concepts and practices (pp. 49-68). San Francisco: Jossey-Bass.

National Task Force on Civic Learning and Democratic Engagement. (2012). A crucible moment: College learning and democracy's future. Washington, DC: American Association of Colleges and Universities. Retrieved from http://www.aacu.org/crucible

Neher, W. W., \& Sandin, P. J. (2016). Communicating ethically: Character, duties, consequences and relationships. New York: Routledge.

Nemeth, E. A., \& Winterbottom, C. (2016). Communities of practice: Youth and social justice service-learning. In A. S. Tinkler, B. E. Tinkler, V. S. Jagla, \& J. R. Strait (Eds.), Service-learning to advance social justice in a time of radical enequality (pp. 298-317). Charlotte, NC: Information Age.

Nicolini, D. (2012). Practice theory, work, and organization. Oxford, UK: Oxford University Press.

Noel, J. (1999). On the varieties of phronesis. Educational Philosophy and Theory, 31(3), 273-289. https://doi. org/10.1111/j.1469-5812.1999.tb00466.x

Noyes, E., Darby, A., \& Leupold, C. (2015). Students' emotions in academic service-learning. Journal of Higher Education Outreach and Engagement, 19(4), 63-84.

Perry, J. A. (2015). The Carnegie project on the education doctorate. Change: The Magazine of Higher Learning, 47(3), 56-61. https://doi.org/10.1080/00091383.2015. 1040712

Pruitt, B., \& Thomas, P. (2007). Democratic dialogue - A handbook for practitioners. Washington, DC and New York: CIDA, GS/OAS, International IDEA, UNDP. Retrieved from http://www.idea.int/publications/democratic_dialogue/index.cfm.

Reay, D. (2004). 'It's all becoming a habitus': Beyond the habitual use of habitus in educational research. British Journal of Sociology of Education, 25(4), 431444. https://doi.org/10.1080/0142569042000236934

Reynolds, N. P. (2014). What counts as outcomes? Community perspectives of an engineering partnership. Michigan Journal of Community Service Learning, 21(1), 79-90. 
Rodgers, C. (2002). Defining reflection: Another look at John Dewey and reflective thinking. Teachers College Record, 102(4), 842-866. https://doi. org/10.1111/1467-9620.00181

Saltmarsh, J., \& Hartley, M. (2011). "To serve a larger purpose". In J. Saltmarsh \& M. Hartley (Eds.), To serve a larger purpose: Engagement for democracy and the transformation of higher education (pp. 1-12). Philadelphia: Temple University Press.

Saltmarsh, J., Hartley, M., \& Clayton, P. (2009). Democratic engagement white paper. Boston: New England Resource Center for Higher Education.

Sandy, M., \& Holland, B. A. (2006). Different worlds and common ground: Community partner perspectives on campus-community partnerships. Michigan Journal of Community Service Learning, 13(1), 30-43.

Schram, S. (2012). Phronetic social science: An idea whose time has come. In B. Flyvbjerg, T. Landman, \& S. Schram (Eds.), Real social science: Applied phronesis (pp. 15-26). New York: Cambridge University Press. https://doi.org/10.1017/CBO9780511719912.003

Schwandt, T. A. (2005). Modeling our understanding of the practice fields. Pedagogy, Culture and Society, 13(3), 313-332. https://doi. org/10.1080/14681360500200231

Shotter, J. (2012). Knowledge in transition: The role of prospective, descriptive concepts in a practicesituated, hermeneutical-phronetic social science. Management Learning, 43(3), 245-260. https://doi. org/10.1177/1350507612437679

Shulman, L. S. (2007). Response to comments: Practical wisdom in the service of professional practice. Educational Researcher, 36(9), 560-563. https://doi. org/10.3102/0013189X07313150

Smith, D. E. (1987). The everyday world as problematic: A feminist sociology. Toronto: University of Toronto Press.

Smith, D. E. (2005). Institutional ethnography: A sociology for people. Lanham, MD: AltaMira.

Sternberg, R. J. (2003). Wisdom, intelligence, and creativity synthesized. New York: Cambridge University Press. https://doi.org/10.1017/CBO9780511509612

Stoecker, R., Tryon, E. A., \& Hilgendorf, A. (Eds.). (2009). The unheard voices: Community organizations and service learning. Philadelphia: Temple University Press.

Torre, M. E., Fine, M., Stoudt, B. G., \& Fox, M. (2012). Critical participatory action research as public science. In P. Camic \& H. Cooper (Eds.), Handbook of research methods in Psychology (pp. 171-184). Washington, DC: American Psychological Association. https://doi. org/10.1037/13620-011

Toulmin, S. (2003). Return to reason. Cambridge, MA: Harvard University Press.

Townley, B. (2014). Bourdieu and organizational theory: A ghostly apparition? In P. S. Adler, P. Du Gay, G.
Morgan, \& M. Reed (Eds.), Oxford handbook of sociology, social theory and organization studies: Contemporary currents (pp. 39-63). Oxford, UK: Oxford University Press.

Vygotsky, L. S. (1978). Mind in society: The development of higher psychological processes. Cambridge, MA: Harvard University Press.

Wade, R. (Ed.). (1997). Community service-learning: A guide to including service in the public school curriculum. Albany, NY: SUNY Press.

Warren, M. R., Park, S. O., \& Tieken, M. C. (2016). The formation of community-engaged scholars: A collaborative approach to doctoral training in education research. Harvard Education Review, 86(2), 233-260. https://doi.org/10.17763/0017-8055.86.2.233

Weick, K. E., Sutcliffe, K. M., \& Obstfeld, D. (2005). Organizing and the process of sensemaking. Organization Science, 16(4), 409-421. https://doi.org/10.1287/ orsc. 1050.0133

Yalowitz, B., Malandra, K., \& Keith, N. (2015). Building trust, sharing power, crossing borders: The art sanctuary-Temple/Tyler Partnership. In N. Z. Keith, Engaging in social partnerships: Democratic practices for campus-community partnerships (pp. 161-189). New York: Routledge.

Yosso, T. J. (2005). Whose culture has capital? A critical race theory discussion of community cultural wealth. Race, Ethnicity and Education, 8(1), 69-91. https:// doi.org/10.1080/1361332052000341006

Zembylas, M. (2007). Emotional capital and education: Theoretical insights from Bourdieu. British Journal of Educational Studies, 55(4), 443-463. https://doi. org/10.1111/j.1467-8527.2007.00390.x

\section{Authors}

NOVELLA Z. KEITH (keithnov@temple.edu) is professor emerita of Urban Education at Temple University. Her work emerges from an abiding interest in participatory democracy and social justice and considers educational partnerships, community service learning, and civic engagement as spaces where these aims can be pursued. This article extends ideas presented in her recent book, Engaging in Social Partnerships: Democratic Practices for University-Community Partnerships (Routledge, 2015). She is currently working on the practical applications of this work with regard to cultivating capacities for democratic engagement in professionals, community partners, and students. 